\title{
Globalization and its Impact on Corporate Entrepreneurship in Nigeria Oil and Gas Industry
}

Chukwuemeka Nnadi*

Department of Management, Faculty of Business Administration, University of Nigeria, Enugu Campus, Enugu State, Nigeria

\begin{abstract}
Globalization is like a sovereign political entity which manages the world resources for common humanity. This renders profit maximization in keeping with corporate policy unacceptable. The pollution and its long neglect resulted in the absence of critical human development infrastructure and restiveness in the forms of militancy, kidnapping functional agents of parent enterprise in host countries and closure of oil operations. Also, the low human indexes of Nigerians render them unemployable in oil and gas industry. In the light globalization the parent enterprise should pursue the maximization of opportunity to benefit all and sundry. The corporate entrepreneurs should have autonomy to effectively manage the MNCs and the environment business. This paper expects them to abide by conventional ethical norms and professional standards for prosperity of common humanity.
\end{abstract}

Keywords: Globalization; Corporate-entrepreneurs; Opportunitymaximization; Prosperity; Common-humanity

\section{Introduction}

Globalization for the purpose trade and commerce is treated as a sovereign political entity of the whole world. Riley [1] defines economic globalization as the process of increasing economic integration between two Countries leading to the emergence of a global market place. This facilitated a truly global division of labour which presents opportunities, for specialization, collaboration and exchange on scales once unimaginable [2]. Multinational corporations manufacture products in many countries and sell to customers around the world. House [3] states that economic globalization is an expanding phenomenon that is reshaping the world into a global village. This fosters a structure of dependence of the developing countries on the industrial nations. This leads them to underdevelopment that deepens and aggravates the fundamental problems of their peoples [4]. It forced the developing countries to want to profit from globalization in the form of increased foreign trade, foreign direct investment and international borrowing. They concentrate on similar cash crops and commodities [5] and rely on a narrow range of primary commodity exports whose world prices are often unstable leading to considerable fluctuation in the incomes of exporting nations [6]. Management of these oil firms in host countries become the responsibility of corporate entrepreneurs. These are hired hands by the parent enterprise based in the home country. What matters is the business insight of the corporate centre. The centre envisions and the organization follows [7]. Therefore, corporate entrepreneurs must not take major personal decisions that can impact positively on their host communities in the face of pollution in the environment where they do oil and gas business. This might diverge significantly from key strategic alignments [8].

\section{Statement of Problem}

1. The long term neglect of the Niger Delta region by the corporate entrepreneurs managing the multinational corporations resulted in the absence of critical human development infrastructure and aggravated the tension in the region.

2. The multinational corporations pursue profit maximization relentlessly in strict compliance with corporate policy which insists that parenting must fit with entrepreneurial initiatives at strategic business unit level in host countries.
3. Nigeria's sole reliance on its oil and gas industry to achieve set millennium goal to become the twentieth developed economy in the world by 2020 is bleak because the industry is managed and controlled by foreign oil firms with their different objectives.

4. The foreign oil and gas firm blatantly refuse to comply with the provision of the Nigerian Content Law and Regulations in its oil and gas industry.

5. The multinational corporations in Nigerian oil and gas industry use their enormous assets much larger than the gross national product of Nigeria or most other African countries to eclipse Nigeria, encroach on its sovereignty, foment distortion in its economy and divert resources from domestic growth.

\section{Objectives of the Study}

1. To find out the effect of the long term neglect of the Niger Delta region by multinational corporation on the environment where they do oil and gas business.

2. To determine the extent to which the parent enterprises have changed the corporate entrepreneurship policy as a result of globalization.

3. To investigate the extent to which the multinational corporations in Nigerian oil and gas industry is disposed to contribute in repositioning Nigeria as the twentieth developed economy in the world by 2020 .

4. To find out the extent to which the foreign oil firms in Nigerian

*Corresponding author: Chukwuemeka Nnadi, Department of Management, Faculty of Business Administration, University of Nigeria, Enugu Campus, Enugu State, Nigeria, Tel: 08066707488; E-mail: chukwuemeka.nnadi@unn.edu.ng

Received May 22, 2014; Accepted July 10, 2014; Published July 20, 2014

Citation: Nnadi C (2014) Globalization and its Impact on Corporate Entrepreneurship in Nigeria Oil and Gas Industry. Int J Econ Manag Sci 3: 173.doi: 10.4172/2162-6359.1000173

Copyright: (C) 2014 Nnadi C. This is an open-access article distributed under the terms of the Creative Commons Attribution License, which permits unrestricted use, distribution, and reproduction in any medium, provided the original author and source are credited 
oil and gas industry have been socially responsible to their host communities.

5. To determine the extent to which the multinational corporations have complied with the Nigerian content laws and regulations.

\section{Research Questions}

1. To what extent has the long term neglect of the Niger Delta region by the multinational corporations affected the environment of the Niger delta region?

2. How have the parent enterprises changed their corporate entrepreneurship, policy as a result of globalization?

3. To what extent would the multinational corporations managing and controlling solely the Nigerian oil and gas industry contribute to repositioning Nigeria as the twentieth developed economy in the world by 2020 ?

4. To what extent have the multinational corporations in Nigerian oil and gas industry been socially responsible to their host communities and their environment?

5. How have the multinational corporations in Nigerian oil and gas industry complied with the Nigerian Content Laws and Regulations?

\section{Review of Related Literature}

Economic globalization, over the last 20-30 years, has transformed human activities, established progressively closer contacts over many centuries and the pace has dramatically increased recently through improvement in transportation and information communication technology (ICT): the confluence of falling trade and investment barriers, revolution in communication and transportation, the opening of China to the West, the collapse of communism and the disintegration of the cold war political barriers, has spawned a highly integrated global economy with vast potential to produce greater wealth and higher living standards [2]. In developed economies globalization is pragmatic in actual circumstances. The global economy is almost being controlled by a small consortium of developed economies. In many industries today, chief competitors come from around the developed countries. For example, the global automobile and other similar industries including home electronics, information technology (IT) services, telecommunication, medical equipment, software development, pharmaceuticals and defence technologies have the same chief competitors from around the developed countries [9]. The current global economic model is enforced through institutions: Such as the World Bank (WB), the International Monetary Fund (IMF) as well as the International Investment Agencies (IIA) and such other bureaucracies (International Forum on Globalization [10]).

Tores [11] defines globalization as a concept by which the whole world for the purpose of trade and commerce is treated as a 'sovereign' political entity, providing numerous opportunities, unfettered access to the world market and capital flow across the globe and sourcing for cheap quality resources. Held et al. [12] affirm that "the contemporary (global) era can claim to have only a single potential hegemonic power: United States of America whose enormous structural power has remained deeply inscribed in the nature and functioning of the present world order.

Daro Acemoglu [1] contends that globalization as we know it today is different from some of the earlier epochs of international integration. According to him globalization has at least four different elements: the first is increased trade integration including outsourcing and an all-round increase in the volume global trade; second is an increase in financial integration such as capital flows between countries, a phenomenon different and distinct from the increase in trade integration, third is the large-scale knowledge integration of the world precipitated by the advert of information knowledge in the form of internet, e-mail etc which makes communication easier from one end of the globe to the other and the fourth-some sort of increased political integration which is not entirely uniform because of breakup of nations and other negative intervening forces. But the nature of international relations has changed since the fall of iron curtain.

Acemoglu et al. [2] advocate of choosing your own capitalism amid the current economic slow down which aroused a renewed interest in what type of capitalism fosters growth and best improves welfare. This curious choice was highlighted in the debate between Mitt Romney and Barrack Obama in the US Presidential elections. The two competing alternatives are: the Nordic-style capitalism and the cut-throat US capitalism. Their study shows that both the US and the Nordic systems have produced prosperous countries and similar growth rates over the past 60years. Nevertheless, significant differences exist between them:

The Nordic societies-Denmark, Finland and Sweden have much strong safe net, more elaborate welfare states, more egalitarian income distribution, with coordinated markets and institutions that provide safely but followers in technological frontiers while the US has the cut-throat capitalism with its extant inequalities, viewed as a more innovative economy, played a leading role in many of the transformative technologies of the last several decades partly because it provides more high-powered incentives to its entrepreneurs and workers who work longer hours, take fewer and shorter vacations and take more risks as well as organize a liberal market and a leader in the technological frontier.

Their study concluded that as a matter of fact given the institutional choices of other countries, if the cut-throat leader were to switch to such cuddly capitalism, this reactionary choice will reduce the growth rate of the entire world economy discouraging the adoption of the more egalitarian reward structure. The discussion of this finding accords with the study the Mcbeth and Rimac [13] that defines the global era as an age of entrepreneurial turbulence. And also the major finding of Foster [14] on the causes for the current of industrial revolution is the theory that 'the British advance was due to the presence of an entrepreneurial class which believed in progress, technology and hard word. The gap in literature shows unequal relationship between the developed economies who are the are countries engaged in capital-intensive production and the developing nations who are on the peripheral areas providing lowskill labour and raw materials and sustaining a structure of dependence.

Nigeria is a country that refuses to develop its people. Even Burundi in theory, makes all levels of education free (Burundi Republique comite central du parti UPRONA 1981) Nigeria uses the obnoxious, abstract and undefined phrase- 'AS AND WHEN PRACTIBLE' in section 18 (3c) 1999 CFRN) provide free education for all including adult literacy. This politically time-celebrated but deceptive phrase provides short term, long term and eternal benefits to politicians and their business fronts. This benefit is in the form of idle fund. Section 308 of Constitution of the Federal Republic of Nigeria (CFRN 1999) empowers politicians in official capacity to live above the law in the management of public fund or its abuse. Nigerians squander their national wealth like infants who do not know the value of things. The multinational corporations exploit Nigerian's internal weak structure. They persevere in the exact fulfillment of their duties and attainment of their sole objective of profit 
maximization. The parenting enterprise policy remains very tight on corporate entrepreneurs' inspite of the influence of globalization that seeks prosperity of common humanity. The stunted political context or the Extractive political elite denies Nigeria and Nigerians a promising and prosperous future. This is because the educational qualification for membership of the National Assembly according to section 65 (2) 1999 CFRN states-"A person shall be qualified for election under section I of this section "if (a) he has been educated up to at least school certificate or its equivalent" Every government is the exact symbol of its people [15]. Nigerians are 'mere' population. Also, the relations in the single world market are unequal because the development of parts of the system occurs at the expense of the other parts as in trade relations based on monopolistic control of the market and financial relations based on loans and export of capital [16]. Corporate social Responsibility tends to be less formalized in terms of CSR benchmarks commonly used in developed countries [17]. The definition of CSR by the World Business Council for sustainable development in its publication- 'Making Good Business Sense' states-CSR is the continuing commitment by business to economic development while improving the quality of life of the work force and their families as well as that of the local community and society at large. The multinational corporations in Nigerian oil and gas industry do not feel that the developing countries deserve the concerns outlined in this definition. Furthermore, the Nigerian content laws and regulations are ignored by the MNCs. In the spirit of globalization, the MNCs should respond to hazards which cause degradation of environment, destruction of aquatic and wild life, vegetation and continuous lights, heat, noise and emission from gas flares [18].

The summary of Review of related literature showed that the World System/Capitalist theory confirms that an advance in production and incentives for long-distance trade is the beginning premise for economic globalization. The MNCs in the developing nations apply unfair standards in the host country of operation because they are militarily weak, without sound background in Economics [19] with low critical human infrastructure as well as having rudimentary technology. The gap in literature is the deliberate deepening of the structure of dependence, a clear affront to the globalization promise of prosperity for common humanity.

\section{Research Methodology}

The study made use of a survey design. It investigated the current behaviour and authority scope of corporate entrepreneurs as agents of the parent enterprise under the influence of globalization through the questionnaire instrument and interview of some of them. In carrying out the study, care was taken to separate the variables that gave thrust to globalization, the independent variable and corporate entrepreneurs, the dependent variable. Its outcome facilitated the design of the research instrument and the analytical tools that helped to discover the relationship between globalization and corporate entrepreneurship of this research. The pre-test interaction in the selected four oil firms provided information on the population of corporate entrepreneurs in each oil firm, the total population and gave clue to the sample size. It helped to perfect the research instrument. The study generated data from both primary and secondary sources. The questionnaire was structured in five-point likert scale. The instrument was checked for reliability using the test re-test method. The reliability co efficient was 0.99. This is shown in Table 1.

$$
\begin{aligned}
& \mathrm{n}=28 \sum \mathrm{X}=16 \sum \mathrm{X}=11 \quad \sum \mathrm{XY}=45 \sum \mathrm{X}^{2}=66 \sum \mathrm{Y}^{2}=31 \\
& \mathrm{r}=\frac{n X_{1} X_{1}-X_{1} Y_{1}}{\sqrt{\left\{Y_{1}^{2}-\left(Y_{1}\right)^{2}\right\}\left\{n X_{1}^{2}-\left(X_{1}\right)^{2}\right\}}}
\end{aligned}
$$

$$
\begin{aligned}
& r=\frac{28(45)-1611}{\sqrt{28(31)-(11)^{2} 28(66)-(16)^{2}}} \\
& r=\frac{1260-176}{\sqrt{868-1211848-256}} \\
& r=\frac{1084}{\sqrt{747 \times 1592}} \\
& r=\frac{1084}{\sqrt{1189224}}=\frac{1084}{1090.5}=\frac{1084}{1091} \\
& r=0.9935 \\
& r=0.99
\end{aligned}
$$

The population of the study is shown in Table 2 .

\section{Sample Size Determination and Sampling Technique}

Sample size determination, using Taro Yamane sampling technique is shown below

$$
\begin{aligned}
& \begin{array}{r}
n=\frac{N}{1+N(e)^{2}} \text { where } \mathrm{n}=\text { sample size } \\
\mathrm{N}=\text { total population } \\
\mathrm{e}=\text { level of significance } \\
1=\text { a constant }
\end{array} \\
& n=\frac{300}{1+300 * 0.0025}=\frac{300}{1+0.75}=\frac{300}{1.75} \\
& \mathrm{n}=171.42857=172
\end{aligned}
$$

Mage [20] states that sample size is properly fixed by deciding the level of accuracy required and determining how large a sampling error is acceptable. Other experts recommend a sample regular proportion, say 5 percent of the population. Yet, some others again insist on a sample size of about 2,000 (two thousand) out of the population. In the light of the above, the study considered a population of 300 as both small and manageable and representative of the firms in question, as the sample size (Table 2.1)

The copies of the questionnaire duly completed and returned were 270 (two hundred and seventy)

Table 3 measured the impact of the policy changes on the corporate entrepreneurs of the multination corporations based on three (3)

\begin{tabular}{|c|c|c|c|c|c|}
\hline Firms & Av. Response Scale (i) $\mathbf{X}$ & Av. Response Scale (ii) $\mathbf{Y}$ & $\mathbf{X Y}$ & $\mathbf{X}^{\mathbf{2}}$ & $\mathbf{Y}^{\mathbf{2}}$ \\
\hline 1 & 5 & 3 & 15 & 25 & 9 \\
\hline 2 & 4 & 3 & 12 & 16 & 9 \\
\hline 3 & 3 & 2 & 6 & 9 & 4 \\
\hline 4 & 4 & 3 & 12 & 16 & 9 \\
\hline Total & $\mathbf{1 6}$ & $\mathbf{4 5}$ & $\mathbf{6 6}$ & $\mathbf{3 1}$ \\
\hline \multicolumn{2}{|c|}{ Table 1: Computation of correlation coefficient. } \\
\end{tabular}

\begin{tabular}{|c|c|c|}
\hline S/N & Oil firms & Numbers of corporate entrepreneurs \\
\hline 1 & Shell PDC Nigeria Plc & 90 \\
\hline 2 & Chevron Oil Nigeria Plc & 75 \\
\hline 3 & Texaco Oil Nigeria Plc & 73 \\
\hline 4 & Agip Oil Nigeria Plc & 63 \\
\hline & Total & $\mathbf{3 0 0}$ \\
\hline \multicolumn{2}{|c|}{ Table 2: Population of Corporate Entrepreneurs. } \\
\hline
\end{tabular}


Citation: Nnadi C (2014) Globalization and its Impact on Corporate Entrepreneurship in Nigeria Oil and Gas Industry. Int J Econ Manag Sci 3: 173. doi: $10.4172 / 2162-6359.1000173$

\begin{tabular}{|l|c|c|}
\hline $\mathbf{S} / \mathbf{N}$ & Oil Firms & Samples Size \\
\hline $\mathbf{1}$ & Shell PDC Nigeria Plc & 90 \\
\hline 2 & Chevron Oil Nigeria Plc & 75 \\
\hline 3 & Texaco Oil Nigeria Plc & 73 \\
\hline 4 & Agip Oil Nigeria Plc & 63 \\
\hline & Total & $\mathbf{3 0 0}$ \\
\hline
\end{tabular}

Table 2.1: Allocation of Sample Size.

\begin{tabular}{|c|c|c|c|c|c|c|}
\hline $\mathrm{S} / \mathrm{N}$ & $\begin{array}{c}\text { Strongly } \\
\text { Agree }\end{array}$ & Agree & Undecided & Disagree & $\begin{array}{l}\text { Strongly } \\
\text { disagree }\end{array}$ & Total \\
\hline $\begin{array}{l}\text { 1. Globalization } \\
\text { exposes corporate } \\
\text { entrepreneurs to } \\
\text { hypercompetition }\end{array}$ & 160 & 59 & 36 & 6 & - & 270 \\
\hline PERCENTAGE & $62.80 \%$ & $21.70 \%$ & $13.30 \%$ & $2.20 \%$ & - & 100 \\
\hline $\begin{array}{l}\text { 2.Globalization } \\
\text { protects corporate } \\
\text { entrepreneurs by } \\
\text { influencing their } \\
\text { autonomy, freedom } \\
\text { and independence in } \\
\text { operation. }\end{array}$ & 67 & 62 & 75 & 26 & 10 & 270 \\
\hline PERCENTAGE & $36.10 \%$ & $22.90 \%$ & $27.70 \%$ & $9.60 \%$ & $3.70 \%$ & 100 \\
\hline $\begin{array}{l}\text { 3. Corporate } \\
\text { entrepreneurs } \\
\text { encompass the } \\
\text { conflicting notions } \\
\text { of individual on one } \\
\text { hand and corporate } \\
\text { development on the } \\
\text { other. }\end{array}$ & 106 & 102 & 36 & 20 & 6 & 270 \\
\hline PERCENTAGE & $39.20 \%$ & $37.90 \%$ & $13.30 \%$ & $7.40 \%$ & $2.20 \%$ & 100 \\
\hline TOTAL & 372 & 223 & 147 & 52 & 16 & 810 \\
\hline Cumulative \% & $45.92 \%$ & $27.53 \%$ & $18.15 \%$ & $6.42 \%$ & $1.98 \%$ & 100 \\
\hline Average & 124 & 74.33 & 49 & 17.33 & 5.33 & \\
\hline
\end{tabular}

Table 3: Impact of Globalization on Corporate Entrepreneurship Policy. Source: Field Survey 2013.

different attributes of corporate policy. The total frequency of responses was eight hundred and ten (810). 372 (45.92\%) of this strongly agreed that globalization impacted on policy changes on corporate entrepreneurs; $160(62.8 \%)$ exposed corporate entrepreneurs to hypercompetitive; 97 (36.10\%) protected them by influencing their autonomy, freedom and independence and 106 (39.20\%) induced them to perform conflicting roles. $223(27.53 \%)$ agreed that globalization impacted on corporate entrepreneurs in multinational corporations while 215(26.55\%) were undecided, disagreed and strongly disagreed that globalization actually impacted on corporate entrepreneurs in multinational corporation in Nigerian oil an gas industry.

The relationship between globalization and corporate entrepreneurship using Chi Square: The average frequencies for the responses were strongly agreed (124), agree (74.33), undecided (49), disagreed (17.33) and strongly disagreed (5.33). These average responses were used in testing hypothesis one (Table 3.1-3.2).

Mean Criterion level $=\frac{5+4+3+2+1}{5}=\frac{15}{5}=3$

Degree of freedom $=(\mathrm{c}-1) \mathrm{x}\left(\mathrm{r}-1^{5}\right)$

Degree of freedom $=\mathrm{df}=(3-1)(5-1)$

$\mathrm{Df}=2 \times 4=8$

Chi-square $x_{c}^{2}=12.27$ - calculated for expected value

$x_{c}^{2}=15.07$ at 0.05 level - contingency table value
Formulating the null and alternate hypothesis

$\mathrm{H}_{\mathrm{o}}: \mathrm{U} \leq 3.00$ (respondents agreed with the claim)

$\mathrm{H}_{\mathrm{A}}: \mathrm{U}>3.00$ (respondents disagree with the claim)

Decision rule: The null hypothesis was accepted if the calculated value of $x_{c}^{2}$ was less than or equal to the critical value in the $x_{t}^{2}$ distribution table, otherwise it was rejected and the alternative hypothesis accepted.

Calculated value of Chi-square $x_{(166)}^{2}=12.27$

Calculated value of Chi-square $x_{c}^{2}=15.07$

Conclusion: since the calculated value of $x_{c}^{2}=12.27<x_{t}^{2}=15.07$ critical value we accepted the null hypothesis. The conclusion was that parent enterprises had not significantly changed their corporate entrepreneurship policy in response to the influence of globalization.

The relationship between Multinational Corporations and Pertinent Nigerian Laws and Regulations using Chi-Square

Table 4 was designed to determine how multinational corporations in Nigerian oil and gas industry complied with the pertient Nigerian laws and regulations in her oil and gas industry. The total frequency of responses was one thousand, six hundred and twenty (1620). Out of this number $615(37.96 \%)$ strongly agreed that multinational corporations in Nigeria oil and gas industry substantially and significantly implemented the pertient Nigerian laws and regulations; 119 (44\%) utilized Nigerian material resources, 36 (13.3\%) met target of $45 \%$ by $2006,76(28.3 \%)$ affirmed the prospect of realizing the target of $70 \%$ by 2010,119 (43.3\%) confirmed that participated of Nigerians stimulated growth and indigenous capacity, 125 (46.2\%) also promoted value adding in Nigerian and 140 (51.9\%) served as an economic engine for job creation and national growth. 484 (29.87\%) agreed, 337(20.8\%) undecided, 126 (7.78\%) disagreed and 58 (1.98\%) strongly disagreed.

The average frequencies were strongly agreed (102.5), agreed (80.67), undecided (56.17), disagreed (21) and strongly disagreed (9.67). These average responses were used in testing hypothesis two.

$$
\text { Mean Criterion level }=5=\frac{15}{5}=3
$$

\begin{tabular}{|l|c|c|c|c|c|}
\hline & N & Minimum & Maximum & Mean & $\begin{array}{c}\text { Std } \\
\text { deviation }\end{array}$ \\
\hline $\begin{array}{l}\text { Globalization exposes } \\
\text { corporate entrepreneurs to } \\
\text { hypercompetitive }\end{array}$ & 270 & 2 & 5 & 4.45 & 0.813 \\
\hline $\begin{array}{l}\text { Globalization protects } \\
\text { corporate entrepreneurs by } \\
\text { influencing their autonomy, } \\
\text { freedom and independence in } \\
\text { operation }\end{array}$ & 270 & 1 & 5 & 3.78 & 1.145 \\
\hline $\begin{array}{l}\text { Corporate entrepreneurs } \\
\text { encompass the conflicting } \\
\text { roles/notions of individual } \\
\text { initiative and corporate } \\
\text { development }\end{array}$ & 270 & 1 & 5 & 4.04 & 1.017 \\
\hline Valid Number (list wise) & $\mathbf{2 7 0}$ & & & & \\
\hline
\end{tabular}

Table 3.1: Descriptive $Y$ items means-Policy Changes on Corporate Entrepreneurs Descriptive Statistics. Source: field survey 2013.

\begin{tabular}{|c|c|c|c|c|}
\hline $\mathrm{N}$ & Minimum & Maximum & Mean & Std Deviation \\
\hline 270 & 6 & 15 & 12.27 & 2.189 \\
\hline
\end{tabular}

Table 3.2: Descriptive Overall mean for Section I Questionnaire Numbers 1, 2 and 3 in Table 3. 
Citation: Nnadi C (2014) Globalization and its Impact on Corporate Entrepreneurship in Nigeria Oil and Gas Industry. Int J Econ Manag Sci 3: 173. doi: $10.4172 / 2162-6359.1000173$

Page 5 of 9

\section{Descriptive overall mean for Section: 11 Questionnaire Nos.} $4,5,6,7,8$ and 9

In all the tables, each mean score was greater than the mean criterion level of 3 (Tables 4.1-4.3). Degree of freedom $=(c-1) \times(r-1)$

$$
\begin{aligned}
& d f=5 \times 4 \\
& d f=20
\end{aligned}
$$

Formulating the null and alternate hypotheses

$\mathrm{H}_{\mathrm{o}}: \mathrm{U} \leq 3.00$ (respondents agreed with the claim)

$\mathrm{H}_{\mathrm{A}}: \mathrm{U}>3.00$ (respondents disagree with the claim)

Decision rule: The null hypothesis was accepted if the calculated value of $x_{c}^{2}$ was less than or equal to the critical value in the $x_{t}^{2}$ distribution table, otherwise it was rejected and the alternative hypothesis accepted.

$S / N$

1. Multinational Corporations utilize Nigerian material resources for provision of and services to the petroleum industry

PERCENTAGE

2. Multinational Corporations met the host country target of $45 \%$ utilization of Nigerian Content by 2006

PERCENTAGE

3. Multinational corporations shall meet the host country target of $70 \%$ utilization of

Nigerian content by 2010

PERCENTAGE

4. Participation of Nigerians in oil and gas activities has stimulated growth in indigenous capacity

\section{PERCENTAGE}

5. Utilization of local raw materials for manufacturing by oil and gas industry goods and provision of services promotes value adding in Nigeria

PERCENTAGE

6. Multinational corporations have transformed the oil and gas industry into an economic engine for job creation and national growth.

\section{PERCENTAGE}

TOTAL

Cumulative \%

Average

\begin{tabular}{|c|c|c|c|c|c|}
\hline Strongly Agree & Agree & Undecided & Disagree & Strongly disagree & Total \\
\hline 119 & 75 & 46 & 24 & 6 & 270 \\
\hline $44 \%$ & $27.70 \%$ & $16.90 \%$ & $9.00 \%$ & $2.40 \%$ & 100 \\
\hline $1.3 .30 \%$ & $11.40 \%$ & $59.90 \%$ & $10.30 \%$ & $5.10 \%$ & 100 \\
\hline 76 & 41 & 93 & 33 & 27 & 270 \\
\hline $28.30 \%$ & $15.10 \%$ & $34.40 \%$ & $12.20 \%$ & $2.40 \%$ & 100 \\
\hline 119 & 109 & 23 & 14 & 5 & 270 \\
\hline $43.30 \%$ & $40.30 \%$ & $8.50 \%$ & $5.10 \%$ & $1.80 \%$ & 100 \\
\hline 125 & 127 & 3 & 12 & 3 & 270 \\
\hline $46.20 \%$ & $47.20 \%$ & $1.10 \%$ & $4.40 \%$ & 1.1 & 100 \\
\hline 140 & 101 & 11 & 15 & 3 & 270 \\
\hline $51.90 \%$ & $37.40 \%$ & $4.10 \%$ & $5.50 \%$ & $1.10 \%$ & 100 \\
\hline 615 & 484 & 337 & 126 & 58 & 1620 \\
\hline $37.96 \%$ & $29.87 \%$ & $20.80 \%$ & $7.78 \%$ & $1.98 \%$ & 100 \\
\hline 102.5 & 80.67 & 56.17 & 21 & 9.67 & \\
\hline$a n$ & 31 & $16 \%$ & & & 270 \\
\hline
\end{tabular}

Table 4: Multinational Corporations and Pertinent Nigerian Laws and Regulations. Source: Field Survey 2013.

Multinational corporations utilize Nigerian material resources for provision of goods and services to petroleum industry

Multinational corporations met the host country's target of $4.5 \%$ utilization....

Multinational corporations shall meet the host country's target of $70 \%$ utilization...

Participation of Nigerians oils and gas activities has stimulated growth of indigenous capacity..

Utilization of local raw material for manufacturing of goods and services by oil and gas industry..

Multinational corporations have transformed the oil and gas industry into economic engine for job creation and national growth

Valid Number (list wise)

\begin{tabular}{|c|c|c|c|c|}
\hline $\mathrm{N}$ & Minimum & Maximum & Mean & Std deviation \\
\hline 270 & 2 & 5 & 4.02 & 1.093 \\
\hline 270 & 1 & 5 & 3.39 & 1.292 \\
\hline 270 & 1 & 5 & 4.17 & 0.97 \\
\hline 270 & 1 & 5 & 4.19 & 0.934 \\
\hline 270 & 1 & 5 & 4.33 & 0.804 \\
\hline $\mathbf{2 7 0}$ & 1 & 5 & 4.33 & 0.883 \\
\hline
\end{tabular}

Table 4.1: Descriptive: Item means- Implementation of Pertinent laws and regulations of host countries by Multinational Corporation: Descriptive Statistics. Source: field survey 2013.

\begin{tabular}{|c|c|c|c|c|}
\hline $\mathbf{N}$ & Minimum & Maximum & Mean & Std Deviation \\
\hline 270 & 9 & 35 & 26.6 & 4.753 \\
\hline
\end{tabular}

\begin{tabular}{|c|c|c|c|c|c|}
\hline & $\mathbf{N}$ & Minimum & Maximum & Mean & Std Deviation \\
\hline $\begin{array}{l}\text { Multinational corporations utilize Nigerian material resources for provision of goods and services to } \\
\text { petroleum industry. }\end{array}$ & 270 & 1 & 5 & 4.02 & 1.093 \\
\hline Multinational corporations met the host country's target of $4.5 \%$ utilization. & 270 & 1 & 5 & 3.39 & 1.292 \\
\hline Multinational corporations shall meet the host country's target of $70 \%$ utilization. & 270 & 1 & 5 & 4.17 & 0.97 \\
\hline Participation of Nigerians oil and gas activities has stimulated growth of indigenous capacity. & 270 & 1 & 5 & 4.19 & 0.934 \\
\hline Utilization of local raw material for manufacturing of goods and services by oil and gas industry. & 270 & 1 & 5 & 4.33 & 0.804 \\
\hline $\begin{array}{l}\text { Multinational corporations have transformed the oil and gas industry into economic engine for job } \\
\text { creation and national growth. }\end{array}$ & 270 & 1 & 5 & 4.33 & 0.883 \\
\hline Valid Number (list wise) & 270 & & & & \\
\hline
\end{tabular}

Table 4.2: Descriptive Overall mean for Section II, Pertinent laws.

Table 4.3: Descriptive: Item means- Implementation of Nigeria Content laws and regulations of host countries by Multinational Corporation: Descriptive Statistics. Source: Field Survey 2013. 
Citation: Nnadi C (2014) Globalization and its Impact on Corporate Entrepreneurship in Nigeria Oil and Gas Industry. Int J Econ Manag Sci 3: 173. doi: $10.4172 / 2162-6359.1000173$

Page 6 of 9

Calculated value of Chi-square $x_{c}^{2}=26.60$

Critical value of Chi-square $x_{t(.05)}^{2}=31.410$

Conclusion: since the calculated value of $x_{c}^{2}=26.60<$ critical table value $x_{t}^{2}=31.410$, we accepted the null hypothesis and rejected the alternate hypothesis. Multinational corporations had not significantly complied with the Nigerian pertinent laws and regulations in her oil and gas (Table 4.3). Table 5 was designed to assess the impact of globalization on the Nigerian oil and gas industry in her national economy based on three (3) different attributes of globalization or global market. The total frequency of responses was eight hundred and ten (810). Out of this number. 345 (39.5\%) strongly agreed that globalization and significant impact: $114(62.8 \%)$ on national economic development and prosperity; but $130(48.2 \%)$ stimulated and supported her manufacturing and service base; but 101 (37.5\%) undermined her export potentials. Also $158(61.4 \%)$ out of 215 agreed but 57 (21.1\%) objected claiming that failure to refine her crude oil in Nigerian undermined Nigerian export potentials. But 250 (30.75) were undecided, disagreed and strongly disagreed.

\section{The relationship between Globalization on National Economy of Nigeria using Chi-Square}

The average frequencies for the responses were strongly agreed (115), agreed (71.67), undecided (52.67), disagreed (25) and strongly disagreed (5.67). These average responses were used in testing hypothesis three (Table 5.1-5.2).

$$
\begin{aligned}
& \text { Mean Criterion level }=5=\frac{15}{5}=3 \\
& \text { Degree of freedom }=(c-1) \times(r-1) \\
& \text { Degree of freedom }=\mathrm{df}=(3-1)(5-1) \\
& \mathrm{df}=2 \times 4 \\
& \mathrm{df}=8
\end{aligned}
$$

formulating the null and alternate hypotheses

$\mathrm{H}_{\mathrm{o}}: \mathrm{U} \leq 3.00$ (respondents agreed with the claim)

$\mathrm{H}_{\mathrm{A}}: \mathrm{U}>3.00$ (respondents disagree with the claim)

Decision rule: The null hypothesis is accepted if the calculated value of chi-square $\left(x_{c}^{2}\right)$ is less than or equal to the critical value or chisquare $\left(x_{t}^{2}\right)$ distribution table, at $\mathrm{df}$ of 8 and $0.05 \%$ level of significance in the distribution table, otherwise it was rejected and the alternative hypothesis is accepted.

Calculated value of Chi-square $x_{t(.0:}^{2}=11.94$

Critical value of Chi-square $x_{t(.05)}^{2}=15.507$

Conclusion: since the calculated value of $x_{c}^{2}=11.94<$ critical value $x_{t}^{2}=15.507$, we accepted the null hypothesis. Therefore, globalization significantly impacted on the national economy in Nigerian oil and gas industry.

Table 6 assessed the impact of multinational corporations on the employment of Nigerians in managerial positions in Nigerian oil and gas industry based on three different attributes of employment services. The total frequency of respondents was one thousand and ninety-eight (810). Out of this number, 290 (35.8\%) strongly agreed that multinational corporations employed Nigerians in managerial position due to external influence; (73 (27.1\%). 102 (38\%) strongly agreed even though Nigerian labour was technologically below standard. Consequently, $115(42.8 \%)$ strongly affirmed that Nigerian graduates and professional served under expatriate technicians). The 249 (30.74\%) that agreed, (78

\begin{tabular}{|c|c|c|c|c|c|c|}
\hline $\mathrm{S} / \mathrm{N}$ & Strongly Agree & Agree & Undecided & Disagree & Strongly disagree & Total \\
\hline $\begin{array}{l}\text { 1. Export of Nigerian crude oil and gas has direct consequencies for national } \\
\text { economic development and prosperity }\end{array}$ & 114 & 88 & 44 & 18 & 6 & 270 \\
\hline PERCENTAGE & $39.50 \%$ & $35.50 \%$ & $16.20 \%$ & $6.60 \%$ & $2.20 \%$ & 100 \\
\hline $\begin{array}{l}\text { 2. Export of crude oil stimulates the economy of Nigeria and supports her } \\
\text { manufacturing and service base }\end{array}$ & 130 & 70 & 23 & 39 & 8 & 270 \\
\hline PERCENTAGE & $48.20 \%$ & $25.90 \%$ & $8.40 \%$ & $14.50 \%$ & $3 \%$ & 100 \\
\hline $\begin{array}{l}\text { 3. Nigeria's failure to refine her crude oil in Nigeria undermines Nigerian's export } \\
\text { potentials }\end{array}$ & 101 & 57 & 91 & 18 & 3 & 270 \\
\hline PERCENTAGE & $37.50 \%$ & $21.10 \%$ & $33.70 \%$ & $6.60 \%$ & $1.10 \%$ & 100 \\
\hline TOTAL & 345 & 215 & 158 & 75 & 17 & 810 \\
\hline Cumulative \% & $42.59 \%$ & $26.54 \%$ & $19.51 \%$ & $9.26 \%$ & $1.98 \%$ & 100 \\
\hline Average & 115 & 71.67 & 52.67 & 25 & 5.67 & \\
\hline
\end{tabular}
(28.9\%), 75 (27.7\%) and 96 (35.5\%) followed the respective attributes in the order presented). 111 (13.70\%) were undecided, 133 (16.42\%),

\begin{tabular}{|c|c|c|c|c|c|}
\hline & $\mathrm{N}$ & Minimum & Maximum & Mean & Std Deviation \\
\hline Export of Nigeria crude oil and gas has direct consequences for national economic development and prosperity & 270 & 1 & 5 & 4.05 & 1.034 \\
\hline Export of crude oil stimulates the economy of Nigeria and supports her manufacturing and service base & 270 & 1 & 5 & 4.02 & 1.193 \\
\hline Nigeria's failure to the refine her crude oil in Nigeria undermines Nigeria's export potentials & 270 & 1 & 5 & 3.87 & 1.036 \\
\hline Valid Number (list wise) & 270 & & & & \\
\hline
\end{tabular}
disagreed and 27 (3.33\%) strongly disagreed (Table 6.1).

Mean Criterion level $=5+4+3+2+1 / 5=\frac{15}{5}=3$
Sample mean $=X=\frac{\sum F X}{\sum F}=\frac{1024.01}{270}=3.79$

Table 5: Impact of Globalization on National Economy. Source: Field Survey 2013.

Table 5.1: Descriptive Item means-Globalization and international trade in Nigeria oil and gas industry. Source: field survey 2013.

\begin{tabular}{|c|c|c|c|}
\hline $\mathrm{N}$ & Minimum & Maximum & Mean \\
\hline 270 & 5 & 15 & 11.94 \\
\hline
\end{tabular}

Table 5.2: Descriptive Overall mean for Section III, Questionnaire Nos 10, 11 and 12. 
Citation: Nnadi C (2014) Globalization and its Impact on Corporate Entrepreneurship in Nigeria Oil and Gas Industry. Int J Econ Manag Sci 3: 173. doi: $10.4172 / 2162-6359.1000173$

Page 7 of 9

\section{$\mathrm{S} / \mathrm{N}$}

1. Most Nigerian managers who work in oil and gas industry are given jobs due to external influence

Percentage

2. The standard of Nigerian labour is far below standard in the mining industry and blurs employment opportunity for Nigerians in managerial positions in oil and gas industry.

Percentage

3. Nigerian graduates and professionals serve under expatriate technicians even though they are more qualified than them academically

\section{Percenatge}

TOTAL

Cumulative \%

Average

\begin{tabular}{|c|c|c|c|c|c|}
\hline Strongly Agree & Agree & Undecided & Disagree & Strongly disagree & Total \\
\hline 73 & 78 & 60 & 57 & 2 & 270 \\
\hline $27.10 \%$ & $28.90 \%$ & $22.30 \%$ & $21.10 \%$ & $0.60 \%$ & 100 \\
\hline $38 \%$ & 75 & 36 & 39 & 18 & 270 \\
\hline 115 & $27.70 \%$ & $13.30 \%$ & 14.45 & $6.60 \%$ & 100 \\
\hline $42.80 \%$ & 96 & 15 & 37 & 7 & 270 \\
\hline 290 & 249 & 111 & 133 & 27 & 810 \\
\hline $35.80 \%$ & $30.74 \%$ & $13.70 \%$ & $16.42 \%$ & $3.33 \%$ & \\
\hline 96.67 & 83 & 37 & 44.33 & 9 & \\
\hline
\end{tabular}

Table 6: Impact of Multinational Corporations on employment of Nigerians in managerial positions in Nigerian oil and gas industry. Source: Field Survey 2013.

\begin{tabular}{|c|c|c|c|c|}
\hline & Scores X & Frequency $\mathrm{F}$ & $\mathrm{FX}$ & $\mathrm{F}\left(\mathrm{X}_{1}-\overline{\mathrm{X}}_{1}\right)^{2}$ \\
\hline Strongly Agree & 5 & 96.67 & 488.35 & $69.67(5-3.79)^{2}=141.14$ \\
\hline Agree & 4 & 83 & 332 & $83(4-3.79)^{2}=3.32$ \\
\hline Undecided & 3 & 37 & 111 & $37(3-3.79)^{2}=23.09$ \\
\hline Disagree & 2 & 44.33 & 88.66 & $44.33(2-379)^{2}=142.04$ \\
\hline Strongly Disagree & 1 & 9 & 9 & $9(1-3.79)^{2}=70.06$ \\
\hline Total & 15 & 270 & 1024 & 379.65 \\
\hline
\end{tabular}

Table 6.1: The relationship between Multinational Corporations and Nigerians in managerial positions in Nigerian oil and gas industry using T-test.

$\mathrm{S} / \mathrm{N}$

1. Multinational corporations as a result of globalization provide social amenities to their host communities

PERCENTAGE

2. Multinational corporations have been employing Nigerians in managerial positions since the impact of globalization

PERCENTAGE

3. Multinational corporations as a result of globalization endeavour to protect their environment of operation in the host communities

PERCENTAGE

4. Multinational corporations in the spirit of globalizations are corporate personalities of Nigerian and should and treat Nigerian as one of its shareholders

PERCENTAGE

TOTAL

Cumulative $\%$

Average

\begin{tabular}{|l|l|l|l|l|l|}
\hline Strongly Agree & Agree & Undecided & Disagree & $\begin{array}{l}\text { Strongly } \\
\text { disagree }\end{array}$ & Total \\
\hline 81 & 120 & 26 & 28 & 15 & 270 \\
\hline $30 \%$ & $44.60 \%$ & $96 \%$ & $10.30 \%$ & $5.50 \%$ & 100 \\
\hline 86 & 104 & 37 & 30 & 13 & 270 \\
\hline $31.90 \%$ & $38.60 \%$ & $13.90 \%$ & $10.80 \%$ & $4.80 \%$ & 100 \\
\hline 111 & 81 & 62 & 13 & 3 & 270 \\
\hline $41 \%$ & $30.10 \%$ & $22.90 \%$ & $4.80 \%$ & $1.20 \%$ & 100 \\
\hline 176 & 62 & 26 & 5 & 1 & 270 \\
\hline $65.10 \%$ & $22.90 \%$ & $9.60 \%$ & $1.80 \%$ & $0.60 \%$ & 100 \\
\hline 454 & 367 & 151 & 76 & 32 & 1080 \\
\hline $42.03 \%$ & $33.98 \%$ & $13.98 \%$ & $7.04 \%$ & $2.96 \%$ & \\
\hline 113.5 & 91.75 & 37.75 & 19 & 8 & \\
\hline
\end{tabular}

Table 7: Multinational Corporations and Corporate Social Responsibility. Source: Field Survey 2013.

Sample variance $S^{2}=\frac{\sum\left(X_{1}-\bar{X}\right)^{2}}{n-1}=\frac{379.65}{270-1}=1.41$

Sample standard deviation $S=\sqrt{1.41}=1.187 \approx 1.19$

Formulating the null and alternate hypotheses:

$\mathrm{H}_{\mathrm{o}}: \mathrm{U} \leq 3$ respondents agreed with claim

$\mathrm{H}_{\mathrm{A}}: \mathrm{U}>3$ respondents disagreed with claim

$\mathrm{df}=\mathrm{N}_{1}+\mathrm{N}_{2}-2(5+3)-2=8-2=6$

$\mathrm{df}=6$

calculating the value of $\mathrm{t}:{ }^{(n-1)}=\frac{\bar{X}-\mu}{s}=\frac{3.79-3}{1.19}=\frac{0.79 \times \sqrt{16.43}}{1.19}=$ $\frac{0.79 \times 16.43}{1.19}=10.91$

$\sqrt{n} \quad \sqrt{270}$

Calculated t-value $=10.91$
Critical value of $\mathrm{t}=2.447$

Decision rule: The null hypothesis was accepted if the calculated value of $t$ is less than or equal to critical table value, otherwise the null is rejected and the alternate hypothesis accepted.

Conclusion: Since the calculated value of $\mathrm{t}(10.91)$ is greater than the critical value of $\mathrm{t}(2.447)$ at $\mathrm{df}=6$ at 0.05 level of significance, we rejected the null hypothesis and accepted the alternate hypothesis.

Table 7 determined the impact of multinational corporations on corporate social responsibility in host communities/host countries based on four different attributes of impacting positively on the environment of operator. The total frequency of respondents was one thousand and eighty (1080). Out of this number, 454 (42.03\%) strongly agreed that multinational corporations are socially responsible, 81 (30\%) of this number strongly agreed that multinational corporations provided social amenities, $86(31.9 \%)$ strongly agreed that multinational 


\begin{tabular}{|c|c|c|c|c|}
\hline & Scores X & Frequency F & FX & $\mathrm{F}\left(\mathrm{X}_{1}-\overline{\mathrm{X}}_{1}\right)^{2}$ \\
\hline Strongly Agree & 5 & 113.5 & 567.5 & $113.5(5-4.1)^{2}=91.94$ \\
\hline Agree & 4 & 91.75 & 367 & $91.75(4-4.1)^{2}=0.92$ \\
\hline Undecided & 3 & 37.75 & 113.25 & $37.75(3-3.79)^{2}=45.68$ \\
\hline Disagree & 2 & 19 & 38 & $19(2-379)^{2}=83.79$ \\
\hline Strongly Disagree & 1 & 8 & 8 & $8(1-3.79)^{2}=76.88$ \\
\hline Total & $\mathbf{1 5}$ & $\mathbf{2 7 0}$ & $\mathbf{1 0 9 3 . 7 5}$ & $\mathbf{2 9 9 . 2 1}$ \\
\hline
\end{tabular}

Table 7.1: The Multinational Corporations and Corporate Social Responsibility in Nigeria using T-test.

corporations employed Nigerians in managerial positions since the impact of globalization, $111(41.1 \%)$ strongly agreed that multinational corporations as a result of globalization endeavoured to protect their environment of operation in the host communities, $176(65.1 \%)$ strongly agreed that multinational corporations in the spirit of globalization are corporate personalities of Nigeria and should regard and treat Nigerian as one of its shareholders. The $367(33.98 \%)$ that agreed, 120 (44.6\%), 104 (38.6\%) 81 (30.1\%) and 62 (22.9\%) followed the respective attributes in the order presented. 151 (13.98\%) were undecided, 76 (7.04\%) disagreed and $32(2.96 \%)$ strongly disagreed in the same order presented (Table 7.1).

Mean Criterion level $=\frac{5+4+3+2+1}{5}=\frac{15}{5}=3$
Sample mean $=X X=\frac{\sum F X}{\sum F}=\frac{1093.75}{270}=4.05 \approx 4.1$
Sample variance $S^{2}=\frac{\sum\left(X_{1}-\bar{X}\right)^{2}}{n-1}=\frac{299.21}{270-1}=1.11$

Sample standard deviation $S=\sqrt{1.11}=1.05$

Formulating the null and alternate hypotheses:

$\mathrm{H}_{\mathrm{o}}: \mathrm{U} \leq 3$ respondents agreed with claim

$\mathrm{H}_{\mathrm{A}}: \mathrm{U}>3$ respondents disagreed with claim

$\mathrm{df}=\mathrm{N}_{1}+\mathrm{N}_{2}-2(5+4)-2=9-2=6$

$\mathrm{df}=7$

calculating the value of $\mathrm{t}$ :

$$
\begin{gathered}
t(n-1)=\frac{\bar{X}-\mu}{s}=\frac{4.1-3}{1.05}=\frac{1.1 \times \sqrt{270}}{1.05}=\frac{1.1 \times 16.43}{1.05}=17.21 \\
\sqrt{n} \quad \sqrt{270}
\end{gathered}
$$

Calculated $\mathrm{t}$-value $=17.21$

Critical value of $\mathrm{t}=2.447$

Decision rule: The null hypothesis was accepted if the calculated value of $t$ is less than or equal to critical value, otherwise the null is rejected and the alternate hypothesis accepted.

Conclusion: Since the calculated value of $\mathrm{t}(17.21)$ is greater than the critical value of $\mathrm{t}$ (2.447) at $\mathrm{df}=7$ at 0.05 level of significance, we rejected the null hypothesis and accepted the alternate hypothesis.

\section{Major Findings}

The following were the research outcomes of the analysis of data

1. Parent enterprises had not significantly changed their corporate entrepreneurship policy in response to overwhelming influence of globalization.
2. There is no significant relationship between impact of globalization and multinational corporations' compliance with the Nigerian (host government) content laws and regulations in Nigerian oil and gas industry: multinational corporations had not significantly complied with the Nigerian oil and gas industry by failing to meet the target of 45 percent in 2006 and 70 percent in 2010 .

3. There was no significant relationship between impact of globalization on national economy in Nigerian oil and gas industry: Globalization had not significantly impacted on the national economy in Nigerian oil and gas industry.

4. There was a significant relationship between impact of globalization and multinational corporations' employment of Nigerians in managerial position in Nigerian oil and gas industry: Multinational corporations had significantly employed Nigerians in managerial position in Nigerian oil and gas industry.

5. There was significant relationship between impact of globalization and multinational corporations' being socially responsible to their host communities. Multinational corporation have significantly been socially responsible to their host communities.

\section{Conclusion}

Corporate Entrepreneurs of multinational corporations in Nigerian oil and gas industry were hired managers by their respective parent enterprises with contract terms and conditions of services with parenting corporate policy which defined their valid operational actions in the host communities where they did business. Unfortunately and undermining the global pursuit of common humanity and global prosperity, corporate entrepreneurs could not take major decisions that impacted positively on their host communities who suffer low critical human development infrastructure and lacked basic social amenities arising from long-neglect of oil pollution etc. Multinational corporations were owned by the core states in the global setting and through the legacy of colonial investments they had established monopolistic/ oligopolistic positions in Nigerian oil and gas industry. Complex technological-driven and capital intensive nature of the industry tended to inhibit effective participation of Nigeria and her establishments-its human and financial capital.

\section{Recommendations}

1. That parent enterprises should provide corporate entrepreneurs a supportive organizational structure/culture to operate with some level of autonomy and independence for innovation, enjoy equal and equitable compensation scheme to enable them take the right risks while ensuring that failure should not be punished. This is because in any corporate venture particularly in oil and gas industry in host country of operations, the probability of failure was (and is) always higher than normal as well as ensure that best talent in the Nigerian market are attracted and retained.

2. Nigerian should acquire the technological sophistication and bridge the required capacity gaps to benefit maximally from the economic opportunities that Nigeria Content Law 2010 set aside solely for Nigerians. Also to stop the primitive and unreliable method of dipping and instantly apply the modern technologies like metering to determine the amount of crude oil 
Citation: Nnadi C (2014) Globalization and its Impact on Corporate Entrepreneurship in Nigeria Oil and Gas Industry. Int J Econ Manag Sci 3: 173. doi: $10.4172 / 2162-6359.1000173$

being lifted. This would provide the Department of Petroleum Resource the scientific device for monitoring with respect to timely and accurate data for oil produced, lifted and exported as well as the exact amount involved.

3. Multinational corporations should build their own refineries in Nigeria for refining Nigeria crude oil in Nigeria to impact positively on international trade in her oil and gas industry as well as improve her manufacturing and service sector and develop critical petroleum related infrastructure to provide ready opportunities to these trained technical personnel in University of Petroleum Warri.

4. Multinational corporations should engage technically proficient Nigerians on merit in managerial positions in the oil and gas industry. Also the employment procedure particularly in oil and gas industry should be based on merit or technical qualification through the recruitment process, selection process and proper placement to enable them to play their roles as Nigerians rather than empire building scenario that put them in positions of employment.

5. In pursuit of global injunction. Niger Delta should ask and even demand that the multinational corporations, comply with Nigerian content laws and regulations in Nigeria (or Niger Delta) protect the environment, act in socially responsible way and abide by conventional ethical norms and professional standards.

\section{References}

1. Riley T (2005) Year 12 Economics, New York: Tim Riley Publication

2. Ikenson D (2009) Made on Earth How Global Economic Integration Renders Trade Policy Obsolete, Washington D.C: Cato Institute No. 42.

3. House RJ (2004) Introduction to culture leadership and organization. The GLOBE Study of 62 societies by Robert House Paul Homges, Manseur Javidan, Peter Dorfman and Vipin Gupta (Thousand Oaks, CA Sage).

4. Santos ID (1970) The structure of Dependence, American Economic Review 60(2): $231-236$
5. Clogan A (2002) Hazardous to Health, The World Bank and IMF in Africa action (on-line).

6. Naomic L, Rethchild P, Stedman, SL (1999) Politics and Society in contemporary Africa. Oxford: Black Well Publishing Ltd.

7. Bieto E, Parada P, Planellas M (2004) Strategic Harmony: The fit between corporate entrepreneurship and parenting, ESADE MBA Business Review (2ndedn), pp:1-2.

8. Viswanathan RJ, Nagarajan GS (2004) The 4E Model, Designing an Incentive system for internal Ventures, ESADE MBA REVIEW (2ndedn).

9. Steers RM, Nardon L (2006) Navigating the culture theory jungle: divergence and convergence in models of national culture, Managing in the Global Economy. New Delhi: Prentice-Hall of India Private Limited.

10. International Forum on Globalization (IFG) (2009) Alternatives to Economic Globalization.

11. Tores R (2001) Towards a socially sustainable world economy: An analysis of the social pillars of globalization, Geneva: ILO.

12. Held D, McGrew A, Goldblatt D, Perranton J (1999) Global Transformation Politics, Economics and Culture. Cambridge: Cambridge Polity press.

13. Mcbeth EW, Rimac T (2004) The age of Entrepreneurial Turbulence, creating sustainable Advantage for Individuals organizations and societies in the New century ESADE MBA Business Review. (2ndedn).

14. Foster C (2004) Capital and Innovation: How Britain Became the first Industrial Nation Northwich: Arley Hall Press, p374.

15. Purvey JP, Farber WD, Tinsley JE, Bjorklund CC (1983) Business Law: Text and Cases, San-Diago: Harcourt Brace Jovanovich, Publishers.

16. Balough T (1963) Unequal Partners in Santos, T.D. the structure of Dependence American Economic Review 60(2): 231-236.

17. Saccom I (2004) A social contact account for CSR as Extended Model of Corporate Governance (Part II) compliancy, Reputation and Reciprocity, Journal of Business Ethics No. 11.

18. News WATCH (1999: 6-14)

19. Samuelson PA (1970) Economics, New York: McGraw-Hill Book Company.

20. Mage J (1965) The Tools of Social Change: An Analytical Description of Social Science Techniques, New York: Anchor Books. 